\title{
The use of Digital Educational Resources in the Process of Teaching and Learning in Pandemic by COVID-19
}

\author{
Ricardo Pocinho \\ CICS.NOVA.IPLeiria, ESECS - \\ Politécnico de Leiria, Leiria, Portugal \\ ricardo.pocinho@ipleiria.pt \\ Rui Santos \\ CICS.NOVA.IPLeiria, ESECS - \\ Politécnico de Leiria, Leiria, Portugal \\ rui.d.santos@ipleiria.pt
}

\author{
Pedro Carrana \\ CIEQV.IPLeiria, Leiria, Portugal \\ pcarrana@gmail.pt
}

\author{
Sandrina Milhano \\ CI\&DEI.IPLeiria, ESECS - Politécnico \\ de Leiria, Leiria, Portugal \\ sandrina.milhano@ipleiria.pt \\ Gisela Santos \\ SCM Sines, Sines, Portugal \\ gisela.ars@gmail.com
}

\author{
Cristovão Margarido \\ CICS.NOVA.IPLeiria, ESECS - \\ Politécnico de Leiria, Leiria, Portugal \\ cristovao.margarido@ipleiria.pt \\ Bruno Trindade \\ Agrupamento de Escola Nuno \\ Alvares, Castelo Branco, Portugal \\ btrindade30@hotmail.com
}

\begin{abstract}
The Coronavirus advance is forcing schools and universities to revise their teaching methodologies. With the closure of the institutions, thousands of teachers and millions of students will have to find new ways of teaching and learning overnight, which will be a huge challenge. We cannot expect everyone to suddenly adapt to these new times. We are aware of the numerous Internet connection problems, but it is a great time to reinvent ourselves and build the courage to test the use of technological tools already available to structure alternatives in the distance education format. Thinking outside the box can help mitigate the momentary problem, as well as collaborate to strengthen digital culture and move towards a new education.The good news is that many teachers have been putting aside prejudices and are being resilient, seeking to understand the potential of available resources, not shying away from seeking and implementing technological solutions that before the virus were seen as secondary and have now become standard tools to teach synchronous and asynchronous classes, share content, correct assignments, answer questions and exchange knowledge. In the beginning, many activities that were previously carried out exclusively in person took a longer time when they started to be performed online. But as the virtual became the new real, students became more engaged and plunged headlong into relevant online learning experiences. Through applications and software, classes continued according to the school calendar.This study aimed to understand how teachers adapted to digital resources to face the limitations caused by the pandemic. It also intends to understand the impact of digital resources on the quality of teaching, as well as on motivation and academic success.
\end{abstract}

Permission to make digital or hard copies of part or all of this work for personal or classroom use is granted without fee provided that copies are not made or distributed for profit or commercial advantage and that copies bear this notice and the full citation on the first page. Copyrights for third-party components of this work must be honored.

For all other uses, contact the owner/author(s).

TEEM'20, October 21-23, 2020, Salamanca, Spain

(C) 2020 Copyright held by the owner/author(s).

ACM ISBN 978-1-4503-8850-4/20/10.

https://doi.org/10.1145/3434780.3436589

\section{CCS CONCEPTS}

- Social and professional topics;

\section{KEYWORDS}

Technology, Educational process, Education, Teachers, COVID-19, Digital resources

ACM Reference Format:

Ricardo Pocinho, Pedro Carrana, Cristovão Margarido, Rui Santos, Sandrina Milhano, Bruno Trindade, and Gisela Santos. 2020. The use of Digital Educational Resources in the Process of Teaching and Learning in Pandemic by COVID-19. In Eighth International Conference on Technological Ecosystems for Enhancing Multiculturality (TEEM'20), October 21-23, 2020, Salamanca, Spain. ACM, New York, NY, USA, 7 pages. https://doi.org/10.1145/3434780.3436589

\section{INTRODUCTION}

The Covid-19 pandemic has brought immense challenges for all sectors, in Portugal and worldwide. In an attempt to reduce the widespread spread of the new Coronavirus, measures of social detachment have been adopted by countries, and it is not yet known exactly when they will no longer be needed. In Education, such measures mean, in general, the closure of public and private schools, with interruption of face-to-face classes. There are already $91 \%$ of all students in the world who are temporarily out of school due to Covid-19 [5, 8, 17, 20-25]. Portugal has followed the world trend. Throughout the national territory, public and private networks have interrupted the functioning of schools and, among other actions, have been considering transferring classes and other educational activities to distance formats.

Given this context, the present effort seeks to use existing data and evidence to illuminate the challenges and limitations of remote education and, also, the strategies that are most appropriate when choosing to use this alternative. The propositional approach that is characterized here is part of an important premise: in the face of an unprecedented scenario that has required public educational authorities to make quick decisions on unprecedented and highly complex issues, analytical productions gain greater adherence and usefulness as they recognize the moment of exceptionality. In this 
line, we try to avoid, for example, a "cold" reading of research on distance learning, which, in general, focuses on comparing "distance classes" with "face-to-face classes" (while, in the current scenario, question is, fundamentally, a discussion between "distance classes" and "not taking classes") [6-10]. In a similar sense, the experiences of countries that interrupted the functioning of schools for long periods due to situations of war, refugee crises, natural disasters and epidemics show that the choice of the public power to do nothing, under the argument that it is not possible reaching everyone, tends to exacerbate the inequalities resulting from the emergency situation [11-14].

In the current context of the provisional closure of schools, in which students will be without face-to-face classes, there is great concern about a possible complete paralysis of the teachinglearning process and the reduction of stimuli that seek the cognitive and socioemotional development of students. In this case, strategies that encourage and support distance activities become essential to reduce the potential effects of the crisis on Education [2, 17, 21]. Therefore, when analyzing the relevance of distance learning strategies in an unprecedented scenario of massive closure of schools, it is crucial to bear in mind that the analysis must have this fact (that is, the absence of classes) as an important parameter of comparison. Even so, the most recent research shows that it is not an equivalent alternative: remote activities, and even more structured activities in the Distance Education modality, have their limitations and, in effect, will not be able to replace the classroom experience, in particular, when applied in scale in Basic Education. Evidence-based literature shows that students who have activities entirely at a distance learn less than those with classroom experience in schools, even taking into account other factors that could affect academic performance [11-15].

And, even when teaching is not entirely distance learning, the evidence is still mixed as to the effects of educational technologies on student learning, in addition to pointing out that many tend to be low cost-effective. Thus, it is necessary to have realistic expectations regarding the various existing solutions, knowing that they are important alternatives at the moment $[5,10,15]$.

Although there are promising educational technologies, their positive results come when they are used in conjunction with faceto-face school activities, which involve student interaction with teachers, tutors and each other (that is, not entirely virtual). In addition, the rapid and complex change that the current scenario requires makes the task even more challenging [16-19]. Difficulties in adapting to the remote education model are natural and should occur even more accentuated in Portugal, since the consistent use of technologies still has a very timid presence in the education networks. Examples of existing obstacles are the lack of knowledge about the quality of most of the available solutions, the little familiarity of students and professionals with distance learning tools and the lack of a family environment that supports and promotes online learning. Thus, it is very likely that, when the period of social detachment ends, students will have significant learning gaps (among other issues).

Currently, there is already a wide range of technologies that can be used in remote education. As a reaction to the crisis caused by the new Coronavirus pandemic, national, international organizations and multilateral organizations have even carried out studies and indicated technological solutions and resources for education networks, schools, teachers and families, aiming, at this moment of social distance, to support the students' learning process $[6,8,15,19]$.

However, it is essential to understand that there are several approaches to distance learning, and that not all are equally effective.

As evidenced by the Learning Sciences evidence, educational technology should not be limited to online class platforms, with slides available, teachers being filmed and exercises to be done. Diversifying learning experiences remains essential and, for this, games, visits to virtual museums, simulations, use of remote laboratories and a series of other resources currently available can be used.28 In addition, pedagogical strategies already recognized as effective in teaching in person can also be used remotely, such as classes that promote the resolution of more complex problems, research and the collaborative construction of knowledge $[3-5,10,12]$.

It is also important to remember that certain contents and subjects are better adapted to virtual teaching than others, so it may be important to analyze, in the curriculum, which competences and skills can be better worked at a distance, so that they are the focus of pedagogical activities in this period of school closure.

In addition to the academic contribution that distance activities can bring at times like this, the experience of countries that have gone through similar crises suggests that there are other important gains when they are organized and worked with consistency. Among them, the contribution that such activities can have to make the home environment more secure and stable stands out, thus rescuing some sense of normality and hope for children, young people and their families, especially those in situations of greater vulnerability [1-4].

Finally, research already shows that the involvement of families in the education of children and young people is essential for their school performance. Issues such as having high expectations about learning, communicating frequently about pedagogical activities and encouraging study and reading habits are some of the main elements indicated by the literature. Undoubtedly, such habits should be further stimulated by public policy in view of the current situation, taking advantage of the fact that students are in direct and frequent contact with their families [1, 2, 5, 9].

In addition, with the crisis, an important opportunity opens up: investing in strengthening the family-school relationship now can bring gains not only in the short term, but, fundamentally, when the classroom dynamics of classes are reestablished. If supported by networks and schools in the post-crisis, it will be a crucial aspect for the return to school phase and, in the medium-long term, highly beneficial for Education more generally.

\section{METHOD}

The present study aimed to analyze all teachers (regardless of the school context) and aims to understand the adaptability of teachers in the pandemic by COVID-19: to develop a diagnostic assessment on how teachers use Digital Educational Resources in the classroom Portuguese public education before and during the pandemic. 


\begin{tabular}{llcl}
\hline & & $\boldsymbol{N}$ & $\%$ \\
\hline Gender & Female & 152 & \\
& Male & 67 & 30.4 \\
& & & 30.6
\end{tabular}

Age

$\begin{array}{lcc}25 \text { a } 30 \text { years } & 4 & 1.8 \\ 31 \text { a } 40 \text { years } & 43 & 19.6 \\ 41 \text { a } 50 \text { years } & 87 & 39.7 \\ 51 \text { a } 60 \text { years } & 64 & 29.2 \\ 61 \text { years or older } & 21 & 9.6\end{array}$

Education Level

$\begin{array}{lll}\text { Postgraduate studies } & 27 & 12.3\end{array}$

Graduation 56

Marter's degree $\quad 66 \quad 30$

Doctorate (PHD) $\quad 70 \quad 32$

Level of education you teach

$\begin{array}{lcc}\text { Pre-school education } & 7 & 3.2 \\ \text { 1st Cycle of Basic Education } & 17 & 7.8 \\ \text { 2nd Cycle of Basic Education } & 33 & 15.1 \\ \text { 3rd Cycle of Basic Education } & 30 & 13.7 \\ \text { Special Education } & 13 & 5.9 \\ \text { Professional Education } & 6 & 2.7 \\ \text { High School } & 32 & 37 \\ \text { University Education } & 81 & 3.2\end{array}$

Locality

$\begin{array}{lcc}\text { North } & 52 & 23.7 \\ \text { Center } & 82 & 37.4 \\ \text { Lisbon and Vale do Tejo } & 49 & 22.4 \\ \text { Alentejo } & 19 & 8.7 \\ \text { Algarve } & 15 & 6.8 \\ \text { Archipelagos Azores e } & 2 & 0.9\end{array}$

Professional experience

\begin{tabular}{lcc} 
Less than 5 years & 16 & 7.3 \\
5 to 10 years & 23 & 10.5 \\
11 to 15 years & 18 & 8.2 \\
16 to 20 years & 40 & 18.2 \\
21 to 30 years & 67 & 30.6 \\
More than 30 years & 55 & 25.1 \\
uation & & \\
Hired & 32 & 14.6 \\
CTFP forward & 25 & 11.4 \\
CTFP indefinitely & 57 & 26 \\
Professionalized & 10 & 4.6 \\
Grouping school & 89 & 40.6 \\
Pedagogical group & 6 & 2.7 \\
\hline
\end{tabular}

Figure 1: Sample (percentages) 


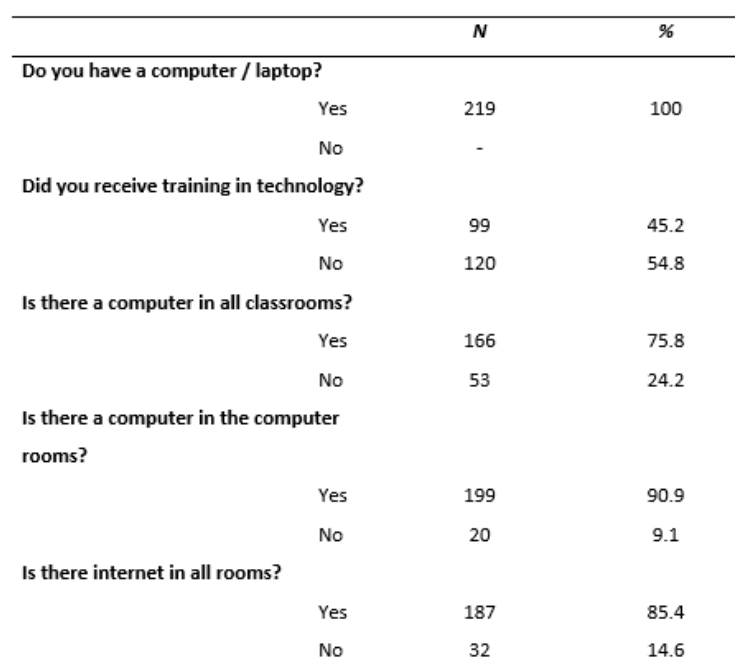

Figure 2: Technological Resources (percentages)

\subsection{Objective}

This study aimed to understand how teachers adapted to digital resources to face the limitations caused by the pandemic. It also allows analyzing which digital resources are most used and how teachers have had to adapt to them.

It also aims to understand the impact of digital resources on the quality of teaching, as well as on school motivation and performance. Other factors such as school integration, difficulties in the management of digital resources and the dedication / effectiveness relationship are also studied.

\subsection{Results}

The evaluation protocol includes a presentation sheet with the objectives and conditions for participation (anonymity, confidentiality and voluntary participation). The questionnaire itself consists of sociodemographic questions as well as questions related to the technological resources that each respondent has (e.g., hardware; software); technological training that the respondent has; resources used for educational purposes; the use of technological resources; impact of digital resources on the quality of school performance.

2.2.1 Sample. The sample (see Figure 1) consists mainly of female teachers $(\mathrm{N}=152 ; 69.4 \%)$. Among the most prevalent age group there is the participation of teachers aged between 41 and 50 years $(\mathrm{N}=87 ; 39.7 \%)$ and 51 to 60 years of age $(\mathrm{N}=64 ; 29.2 \%)$, mostly with academic qualifications at $\mathrm{PhD}$ level $(\mathrm{N}=70 ; 32 \%)$.

Regarding the educational context in which they teach, $3.2 \%(\mathrm{~N}=$ 7) are teachers in pre-school education, $15.1 \%(\mathrm{~N}=30)$ are teachers of the 2nd Cycle of Basic Education, 5.9\% are in special education $(\mathrm{N}=13), 2.7 \%$ are from vocational education $(\mathrm{N}=6), 37 \%$ are from secondary education $(\mathrm{M}=32)$ and $30.2 \%$ are from higher education $(\mathrm{N}=81)$. The sample consists mainly of Higher Education Teachers.

The majority of the sample resides in the center of the country $(\mathrm{N}=82 ; 37.4 \%), 23.7 \%$ resides in the north $(\mathrm{N}=52), 22.4 \%$ resides in Lisbon and Vale do Tejo $(\mathrm{N}=49), 8.7 \%$ resides in the Alentejo $(\mathrm{N}=$

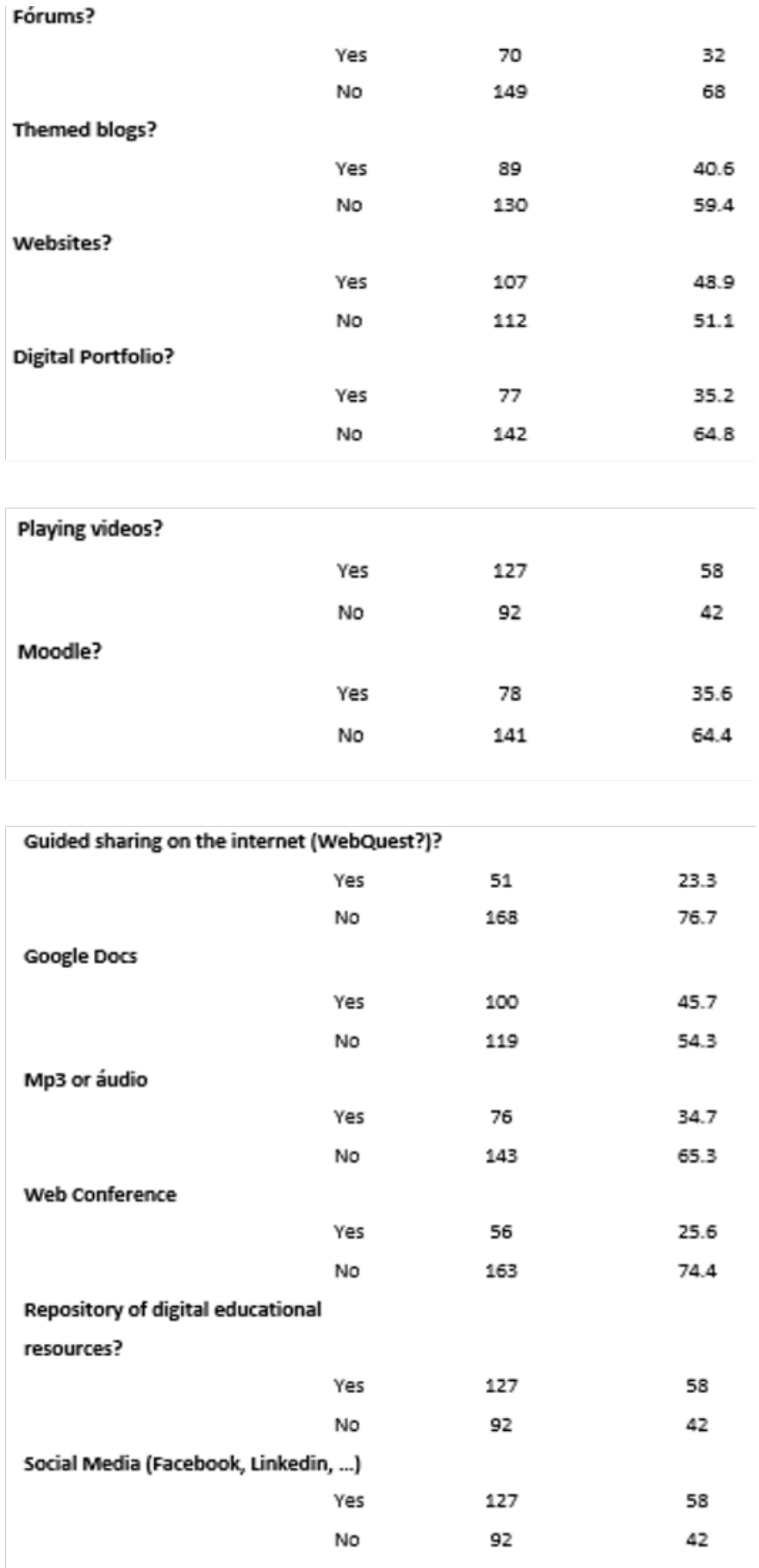

Figure 3: Before the pandemic - what technological resources did teachers use? (percentages)

19), $6.8 \%$ live in the Algarve $(\mathrm{N}=15), 0.9 \%$ live in the archipelagos $(\mathrm{N}=2)$. 


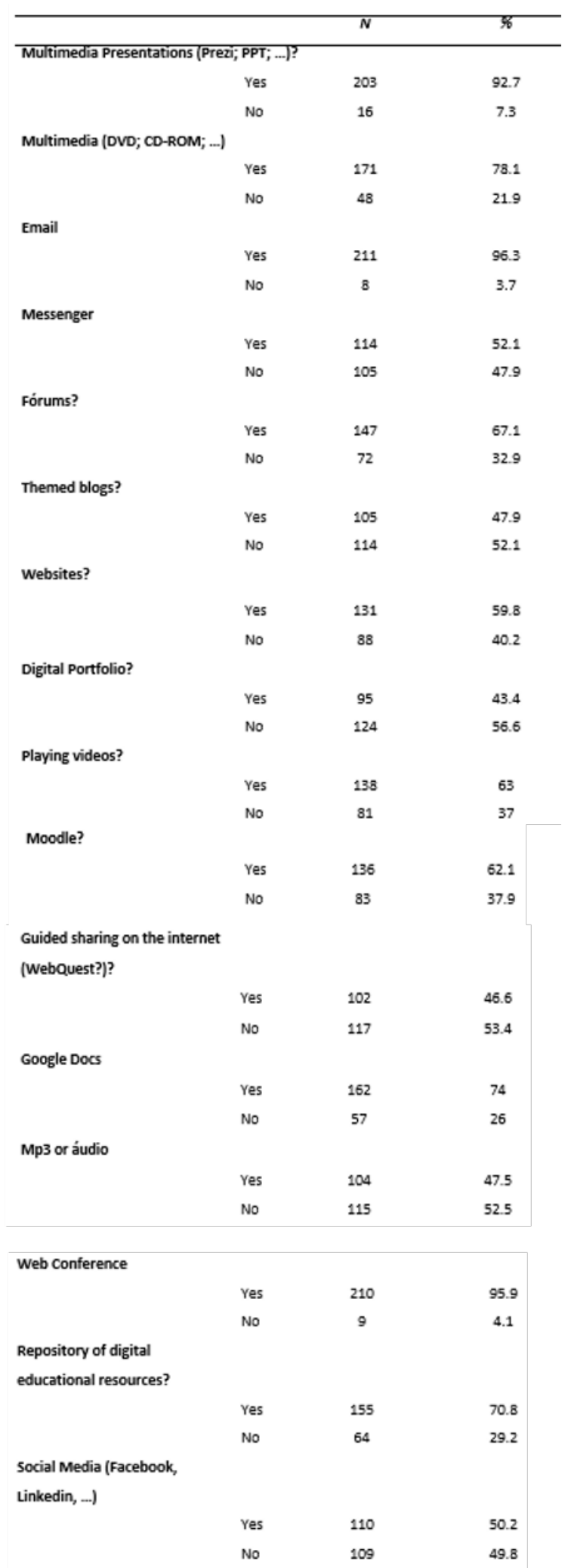

Figure 4: During the pandemic - what technological resources did teachers use? (percentages)

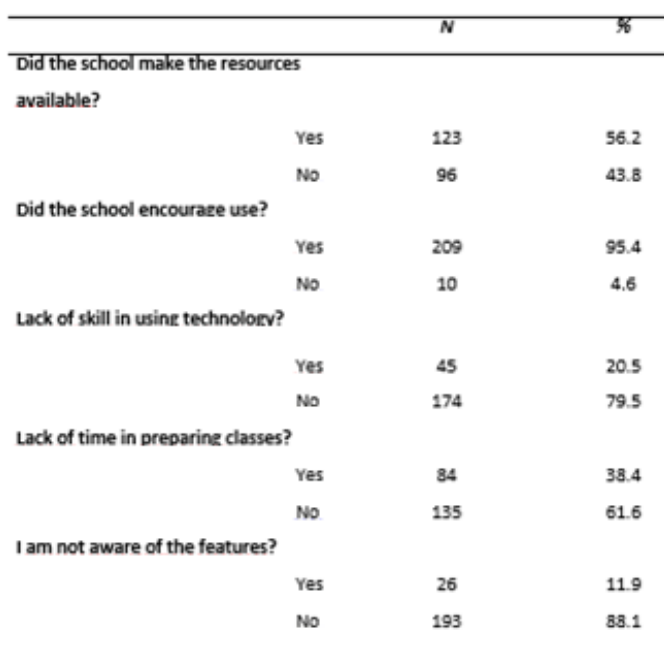

Figure 5: Difficulties experienced in the use of digital resources (percentages)

Most teachers are active between 21 to 30 years of service $(\mathrm{N}=$ $67 ; 30.6 \%)$ and more than 30 years of service $(55 ; 25.1 \%)$. The vast majority are effective at work $(\mathrm{N}=89 ; 40.6 \%)$.

2.2.2 Technological Resources. With regard to the technological resources (see Figure 2) that teachers could access during the pandemic by COVID-19, it was found that all teachers have access to a fixed computer per teacher $(\mathrm{N}=219 ; 100 \%)$. The vast majority did not have specific training in the area of technology $(\mathrm{N}=120$; $54.8 \%)$. The rooms have a computer $(\mathrm{N}=166 ; 75.8 \%)$ and there is an internet connection in practically all rooms $(\mathrm{N}=187 ; 85.4 \%)$.

2.2.3 Before the pandemic - what did technological resources teachers use. It was intended to analyze the technological resources used by teachers before the pandemic (see Figure 3). It was found that teachers used multimedia presentations (for example, Prezi) $(\mathrm{N}=$ 206 ; 94.1), resort to multimedia $(\mathrm{N}=168 ; 76.7 \%)$, Email $(\mathrm{N}=171$; $78.1 \%)$, Video playback $(\mathrm{N}=127 ; 58 \%)$, digital educational resources $(\mathrm{N}=127 ; 58 \%)$ and social networks (for example, Facebook) $(\mathrm{M}=$ $127 ; 58 \%)$. They did not use Messenger $(\mathrm{N}=166 ; 75.8 \%)$, forums $(\mathrm{N}=$ $149 ; 68 \%)$, blogs $(\mathrm{N}=130 ; 59.4)$, thematic websites $(\mathrm{N}=112 ; 51.1 \%)$, digital portfolio $(\mathrm{N}=142 ; 64.8 \%)$, Moodle $(\mathrm{N}=141 ; 64.4)$, Google docs $(\mathrm{N}=119 ; 54.3 \%)$, MP3 $(\mathrm{N}=143 ; 65.3 \%)$, WEB conference $(\mathrm{N}=$ $163 ; 74.4 \%)$.

2.2.4 During the pandemic - what technological resources did teachers use. It was intended to analyze the technological resources used by teachers during the pandemic (see Figure 4). During the pandemic it was found that teachers used almost all digital resources, even those that before the pandemic did not use, with the exception of thematic blogs $(\mathrm{N}=114 ; 52.1 \%)$, digital portfolio $(\mathrm{N}=124 ; 56.6 \%)$, MP3 $(\mathrm{N}=115 ; 52.5 \%)$.

2.2.5 Difficulties experienced in the use of digital resources. It was intended to analyze the technological resources used by teachers during the pandemic (see Figure 5). During the pandemic it was 


\begin{tabular}{lccc}
\hline & & $N$ & 96 \\
\hline Attention & Yes & 168 & 76.8 \\
& No & 51 & 23.2 \\
Learning & & & \\
& Yes & 170 & 77.6 \\
& No & 49 & 22.4
\end{tabular}

School motivation

$\begin{array}{lccc} & \text { Yes } & 171 & 78.1 \\ & \text { No } & 48 & 21.9 \\ \text { Student / Teacher Interaction } & & 145 & \\ & \text { Yes } & 74 & 66.2 \\ & \text { No } & & 33.8 \\ \text { School success } & & 182 & \\ & \text { Yes } & 37 & 83.1 \\ \text { School integration } & \text { No } & 46 & 16.9 \\ & & 173 & 21 \\ \text { Decrease in deviant behaviors } & & & 79 \\ & \text { No } & 125 & 57.1\end{array}$

Figure 6: Impact of the use of digital resources (percentages)

\begin{tabular}{llll} 
& & N & \% \\
\hline Classes s preparation & Difficult & 93 & 42.4 \\
& Easy & 126 & 57.6 \\
Classes's apllication & & & \\
& Difficult & 64 & 29.8 \\
& Easy & 155 & 70.2
\end{tabular}

Figure 7: What is the level of difficulty in using the classes (percentages)

found that teachers used almost all digital resources, even those that before the pandemic did not use, with the exception of thematic blogs $(\mathrm{N}=114 ; 52.1 \%)$, digital portfolio $(\mathrm{N}=124 ; 56.6 \%), \mathrm{MP} 3(\mathrm{~N}=$ $115 ; 52.5 \%)$.

2.2.6 Impact of the use of digital resources. The use of digital resources in online classes, during the pandemic, allowed students to improve their attention $(\mathrm{N}=168 ; 76.8 \%)$, improved learning $(\mathrm{N}=$ $170 ; 77.6 \%)$, increased school motivation $(\mathrm{N}=171 ; 78.1 \%)$, improved the relationship between student and teacher $(\mathrm{N}=145 ; 66.2 \%)$, increased school performance $(\mathrm{N}=182 ; 83.1 \%)$, and decreased deviant behaviors $(\mathrm{N}=125 ; 57.1 \%)$. It was also found that school integration was impaired ( $\mathrm{N}=173 ; 79 \%)$ (see Figure 6).

2.2.7 What is the level of difficulty in using the classes. Teachers do not seem to have had difficulties in preparing online classes $(57.6 \%)$ or in applying digital resources in distance learning during the pandemic $(70.2 \%)$ (Figure 7).

\section{CONCLUSIONS}

This study aimed to understand how teachers adapted to digital resources to face the limitations caused by the pandemic. It also intends to understand the impact of digital resources on the quality of teaching, as well as on motivation and academic success.

With this in mind, and when observed together, the messages presented point to the understanding that, at this moment, the best use of distance learning is that which is guided by a strategy that recognizes the existing risks, having a close look at the equity and that, fundamentally, supports teachers to go ahead of the teachinglearning process. Even so, the position recorded in the first message of this document is reiterated: given the context, however consistent the adopted strategy may be, it can, at best, minimize negative impacts. Therefore, only a good planning and execution of the return to school, which recognizes the multiple dimensions that will need to be addressed, will be able to adequately respond to the challenge imposed.

\section{REFERENCES}

[1] Ahn, J. e McEachin, A. (2017). Student Enrollment Patterns and Achievement in Ohio's Online Charter Schools. Educational Researcher, Vol. 46.

[2] Banco Mundial (2020b). Remote Learning and COVID-19: The use of educational technologies at scale across an education system as a result of massive school closings in response to the COVID-19 pandemic to enable distance education and online learning. Versão de 16 de março de 2020.

[3] Banerjee, A., Cole, S., Duflo, E. e Linden, L. (2007). Remedying Education: Evidence From Randomized Experiments in India. The Quarterly Journal of Economics 122(3).

[4] Barrera-Osario e Linden, L. (2009). The Use and Misuse of Computers in Education: Evidence from a Randomized Controlled Trial of a Language Arts Program. Working Paper, Columbia University.

[5] Campos, C. (2020). Educação e Covid-19: Um levantamento das respostas de órgãos federais e estaduais à epidemia.

[6] CDE (2010). Summary report of the operations and activities of online programs in Colorado. Colorado Department of Education, Denver, CO.

[7] Cetic (2018a). Pesquisa TIC Domicílios 2018. Centro Regional de Estudos para o Desenvolvimento da Sociedade da Informação. Acesso em: 26/03/2020.

[8] Chang, G. e Yano, S. (2020). How are countries addressing the Covid-19 challenges in education? A snapshot of policy measures. Section of Education Policy Unesco.

[9] Cheung, A. e Slavin, R. (2012). How features of educational technology applications affect student reading outcomes: A meta-analysis. Education Research Review, v.7(3)

[10] Cheung, A. e Slavin, R. (2013). The effectiveness of educational technology applications for enhancing mathematics achievement in K-12 classrooms: A metaanalysis. Education Research Review, v.9.

[11] Craig, R. (2020). What Students Are Doing Is Remote Learning, Not Online Learning. There's a Difference. Opinion - EdSurge.

[12] CREDO (2019). Charter school performance in Ohio. Center for Research on Education Outcomes - Stanford University. CREDO (2015). Online Charter School Study. Center for Research on Education Outcomes - Stanford University

[13] Fox, R. (2004). SARS epidemic: Teachers' experiences using ICTs. University of Hong Kong.

[14] INEE (2016). Psychosocial Support and Social and Emotional Learning for Children and Youth in Emergency Settings. Inter-Agency Network for Education in Emergencies (INEE) Background Paper.

[15] OCDE (2015). Schooling Redesigned: Towards Innovative Learning Systems. Centre for Educational Research and Innovation (CERI) - OCDE.

[16] OCDE (2018). Understanding Innovative Pedagogies: Key Themes to Analyse New Approaches to Teaching and Learning. OCDE - Education Working Paper No. 172.

[17] OCDE (2020). A framework to guide an education response to the COVID-19 Pandemic of 2020. OCDE.

[18] Sawyer, R.K. (2008). Optimising Learning: Implications of Learning Sciences Research. Centre for Educational Research and Innovation (CERI) - OCDE.

[19] Sawyer, R.K. (2014). The Cambridge handbook of the learning sciences (2nd edition). Cambridge Univ. Press, Cambridge.

[20] Soares, J.F., Castilho, E. e Ernica, M. (2019). IDeA - Indicador de Desigualdades e Aprendizagens - Relatório de Análise. Projeto IDeA - Fundação Tide Setubal. 
[21] Unesco (2020a). Global Monitoring of school closures caused by COVID-19. Disponível em: https://en.unesco.org/ themes/educationemergencies/coronavirus-school-closures. Acesso em 08/04/2020.

[22] Unesco (2020b). COVID-19: 10 Recommendations to plan distance learning solutions. Disponível em:https:// en.unesco.org/news/covid-19-10-recommendationsplan-distance-learning-solutions. Acesso em 26/03/2020. Unesco (2020c).

[23] Distance learning solutions. Disponível em: https://en.unesco.org/themes/ education-emergencies/ coronavirus-school-closures/solutions. Acesso em $25 / 03 / 2020$
[24] União Europeia (2020). Commission and European regulators calls on streaming services, operators and users to prevent network congestion. Disponível em https://ec.europa.eu/digital-single-market/en/news/commission-andeuropeanregulators-calls-streaming-services-operators-and-lusers-prevent-network. Acesso em 02/04/2020.

[25] Unicef (2020). Covid-19: Mais de 95\% das crianças estão fora da escola na América Latina e no Caribe. Disponível em: https://www.unicef.org/brazil/comunicadosde-imprensa/covid-19-mais-de-95-por-cento-das-criancas-fora-daescola-naamerica-latina-e-caribe. 